\title{
MANUSCRIPTS AND BROADSHEETS. NARRATIVE GENRES AND THE COMMUNICATION CIRCUIT AMONG WORKING- CLASS YOUTH IN EARLY 20th-CENTURY FINLAND
}

\author{
Kirsti Salmi-Niklander
}

\begin{abstract}
This article explores the hazy boundary between folklore and literature, orality and literacy in relation to the individual and the community. How do people who belong to the first generation of active writers in their family and community express their own experiences through fictional narratives and the literary tradition? This question is explored in relation to the working-class youth in the small industrial community of Karkkila (Högfors) in southern Finland. The most important research materials are the editions of hand-written newspapers written by these young people from 1914 to 1925 .

My theoretical background is derived from both folklore studies and book history. Inspired by the research of Robert Darnton, I have outlined the communication circuit of the working-class youth during the early 20th century, discussing the position of the manuscript tradition (hand-written newspapers, manuscript songbooks, minutes) in relation to the printed texts (books, newspapers, broadsheets) and the oral tradition. In my article I focus on the narratives of love in the manuscripts written by the working-class youth. How do they work with the ideas and narrative genres and themes adopted from the printed media and the oral tradition? I outline fictionalization of personal experiences and localization of fictional, printed texts as two basic narrative strategies utilized in these processes.
\end{abstract}

Key words: broadsheets, communication networks, fictionality, folk songs, hand-written newspapers, literacy, manuscript tradition, narratives of love, orality, working-class youth

Narrative as a theoretical concept and as a methodological tool has been intensively discussed both by folklorists and literary historians. This article explores the hazy boundary between folklore and literature, orality and literacy, in relation to the individual and the community. How do people who belong to the first generation of active writers in their family and community express their own experiences through fictional narratives and the literary tradition?

My conclusions are based on a case study of the literary activities of young working-class people in Karkkila (Högfors) ${ }^{1}$, a small industrial community in southern Finland, in the 1910s and 1920s. During this period, the young men and women of this community produced a large collection of hand-written newspapers named Valistaja (The Enlightener). The paper was confiscated by the police in 1926 because of the communist political orientation of its writers. It provided a medium for discussing political questions and practising literary genres. At the beginning of the 1980s, a pile of issues of The Enlightener was found in the attic of the local 
police station. The preserved collection runs to 550 pages and this is probably only about half of the original material. It is the most important material in my doctoral thesis Self-Education and Rebellion (Salmi-Niklander 2004). ${ }^{2}$

The writers of The Enlightener, young unmarried men and women in their late teens and early twenties, were the first fully literate generation in their families and in their community. As historian Kimmo Rentola (1992: 274-284, 394-399, 440-441) has pointed out, the parish of Pyhäjärvi was an isolated community, in which traditional soothsaying and burnt-over cultivation were still practised at the beginning of the 20th century, and the majority of the grown men still used signs instead of signatures in official documents.

The young people of the 1910s and the 1920s had experienced many rapid changes during their childhood and youth: the Högfors ironworks, which had been started in 1820, was expanded into the largest of its kind in Finland; and the workers' movement and the primary school system were established simultaneously during the first decade of the 20th century. Karkkila is a community with strong contrasts and tensions, which can still be experienced in the local culture today (Rentola 1992: 440-441, 467-469, 518-526; Valpola 1999).

\section{THE MANUSCRIPT TRADITION AND THE COMMUNICATION CIRCUIT}

The history of reading, writing and publishing has become an innovative field of interdisciplinary research during the last decade. "The information revolution" at the turn of the millennium has awoken a new kind of interest in written and oral media, and in their history. ${ }^{3}$ The relationship between print and manuscript culture has also been re-evaluated. Michael Bristol and Arthur Marotti (2000: 13-14) point out that the manuscript medium served certain socio-political functions for several centuries after the Gutenberg revolution. They summarize the results of recent research: "[M] anuscript transmission belonged to a culture that valued personal intimacy, sociality and participation, if not also intellectual and social exclusivity - all features that generally distinguished it from print."

Combining theoretical viewpoints of folklore studies and book history is vital for research on the manuscript tradition. Folklore studies is a fruitful basis for studying the relationship between the oral and the written, whereas book history provides tools for considering questions that deal with writing and publishing, facts that are essential in the process of becoming a modern citizen. According to my observations, individualism and collectivism are not binary oppositions in this process - they are complementary phenomena. Hand-written newspapers have provided many self-educated people with their first possibilities to present their ideas and writings to a wider group of people. On the other hand, they have functioned as collective writing, as several people have participated in the creation of individual texts, and the identity of individual writers has often been hidden. 
Robert Darnton (1995: 189; 2000: 7-9) has developed a model of the communication circuit in 18th-century Paris, in which he includes printed, manuscript and oral media. Darnton (2000: 26) emphasizes the creativity of this process:

It always involved discussion and sociability, so it was not simply a matter of messages transmitted down the line of diffusion to passive recipients but rather a process of assimilating information in groups - that is, the creation of collective consciousness or public opinion.

I have applied Darnton's model and outlined the communication networks of working-class youth at the beginning of the 20th century (Fig. 1), and discuss the position of the manuscript tradition (handwritten newspapers, manuscripts, letters and diaries) in relation to the printed texts (books, newspapers, journals and broadsheets) and the oral tradition (folk songs, legends and anecdotes in folklore collections).

The first decades of the 20th century comprised a period of many dramatic events in the history of Finland, culminating in the Civil War between the Red and the White Guards in 1918. It was also a period of transition in the history of communication. Many old forms of media, such as broadsheets and hand-written newspapers, had their last heyday and assumed new significance during the periods of censorship and political oppression. At the same time new media such as telephones, gramophones and the radio started to get established. Narrative genres of oral tradition had a rich interaction with these media.

I have traced the historical roots of hand-written newspapers to several cultural phenomena of the early modern era: newsletters, the salon culture and the correspondence networks of religious sects (see, e.g., Mäkinen 1997: 126-127). Handwritten newspapers were marginalised as family and school tradition in most countries during the 19th century, but in Finland they were revitalised by university students, and later by the leaders of agrarian youth movement and the workers' movement. ${ }^{4}$ By the beginning of the 20th century they were no longer a marginalising genre, but were expanding into new social groups and local communities.

New groups taking up this tradition adopted not only the basic idea of writing a journal by hand, but also the genres and expressive formulae. Genres typical of handwritten newspapers written in different times and different communities include parodic news and advertisements, which are also common in printed comic magazines. Hand-written newspapers were not just copies and imitations of printed texts, but they also served as a medium that enabled and encouraged literary creativity and experimentation.

\section{FICTIONALISATION AND LOCALISATION}

I consider the fictionalisation of personal experiences and the localisation of fictional, printed texts two basic narrative strategies in the complex interaction between oral communication and printed and manuscript media (Salmi-Niklander 


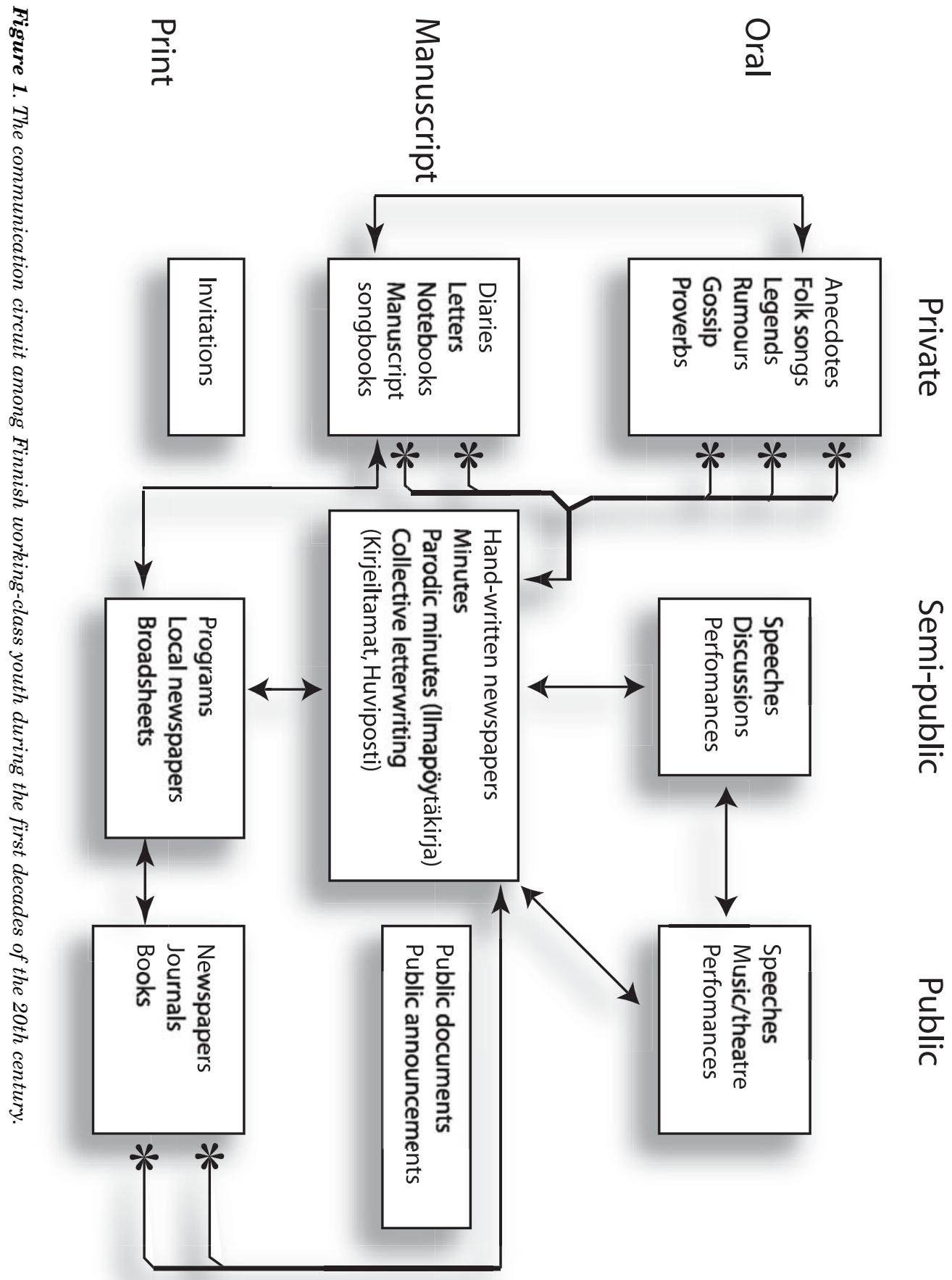


2004: 175-178). A typical genre of hand-written newspapers is the "local event narrative", which means a description of an event in a local community - an excursion, a meeting, a social evening or a festival (Salmi-Niklander 2004: 137140). This genre of writing could be compared with the "personal experience narrative" (Stahl 1989). Although the topics of "local event narratives" are simple, the writers utilise various literary methods - narration, metaphors and literary citations - in order to fictionalise their own experiences.

Localisation, on the other hand, includes different means of rewriting and reinterpreting printed texts in a local context. This process is comparable to the localisation of oral narratives, which according to Lauri Honko (1981: 19-21) means the adaptation of an oral narrative, often a historical legend, to a new setting and physical milieu to where it does not originally belong. ${ }^{5}$

The rewriting of a printed text into the manuscript medium, however, is a more conscious activity than the adaptation of oral narratives. The writers of handwritten newspapers of the 19th and the 20th century were aware of the norms regarding plagiarising. The comparable phenomena of copying and rewriting were typical of the manuscript culture of the early modern period. James Bristol and Arthur Marotti (2000: 5) described manuscript communication as a literary environment in which "texts were malleable and social rather than fixed and possessively individualistic."

\section{"LOADS OF TEXTUAL DYNAMITE"}

During my long research process with The Enlightener some texts have provided apparently endless scope for new interpretations when I analysed them in new theoretical and intertextual contexts. I have described these texts as "loads of textual dynamite". Many of these texts are narratives of love, which was an extremely interesting yet delicate topic for the young men and women concerned. Even on the first reading I sensed the ambiguous emotions in them: hate, bitterness and frustration as well as love, friendship and compassion. Studying the intertextual context in relation to the communication networks has helped me to analyse their emotional dynamics. The writers, readers and performers rejected some forms of behaviour and ways of thinking, and at the same time explored new alternatives.

Besides The Enlightener, the most important sources on the narratives of love among the working-class youth of Karkkila were the collections of Kustaa Raunio and Ida Lusenius at the Folklore Archives of the Finnish Literature Society. Kustaa Raunio (1875-1945) (Fig. 2) was a shoemaker, who was born in Karkkila and returned there with his family in the 1920 s. He sent a collection of songs, proverbs and legends to the Great Folklore Collection Contest, which was part of the Kalevala Jubilee of 1935 . It was a collection that included quite a few men's songs of sexual content, but he did not indicate the sources of most of them. They were sung in his shoemaker's shop, where young men used to spend their spare time. ${ }^{7}$ 


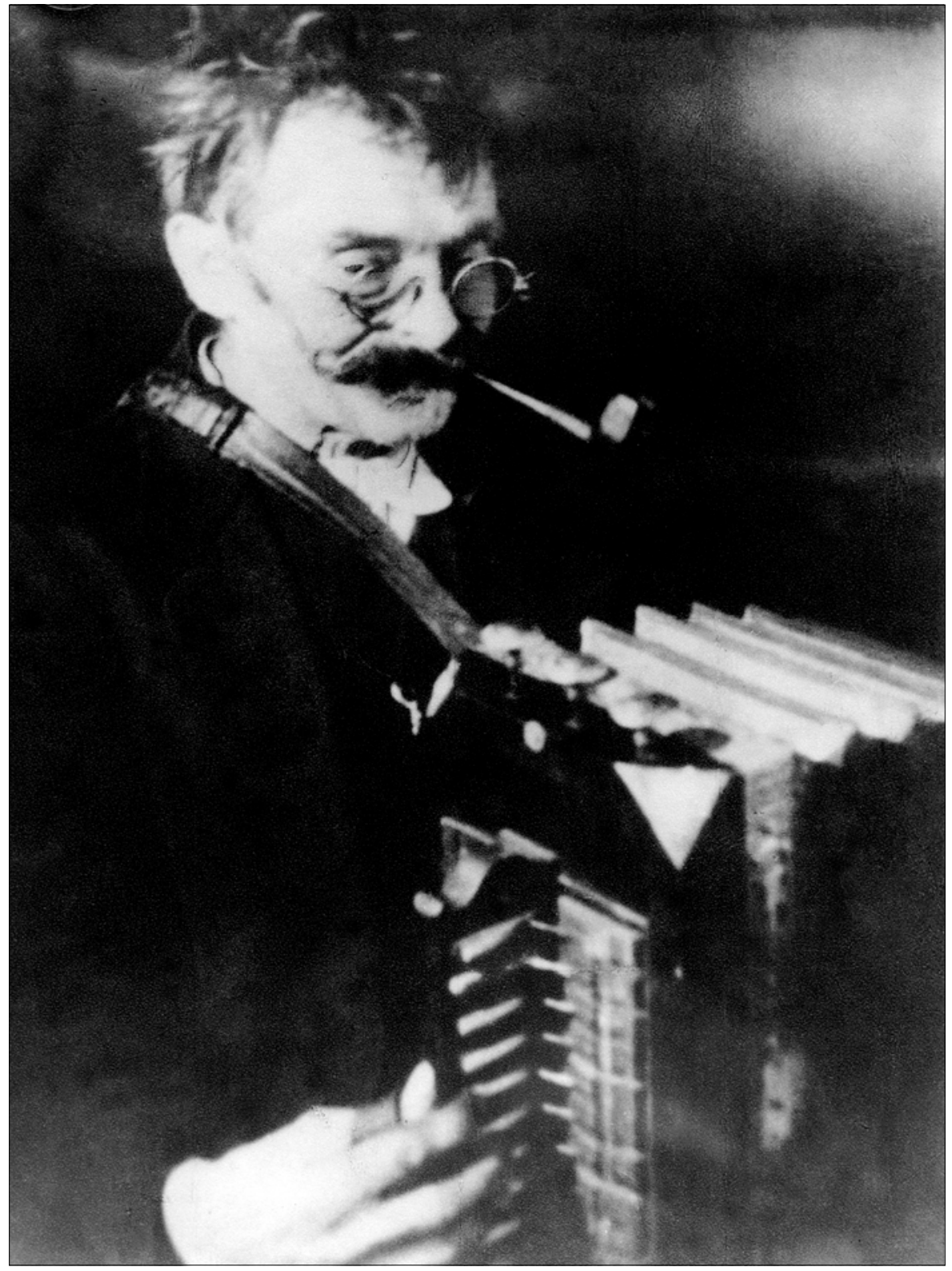

Figure 2. Shoemaker Kustaa Raunio with his accordion. Source: private collection of AnnaLiisa Lindstedt. 


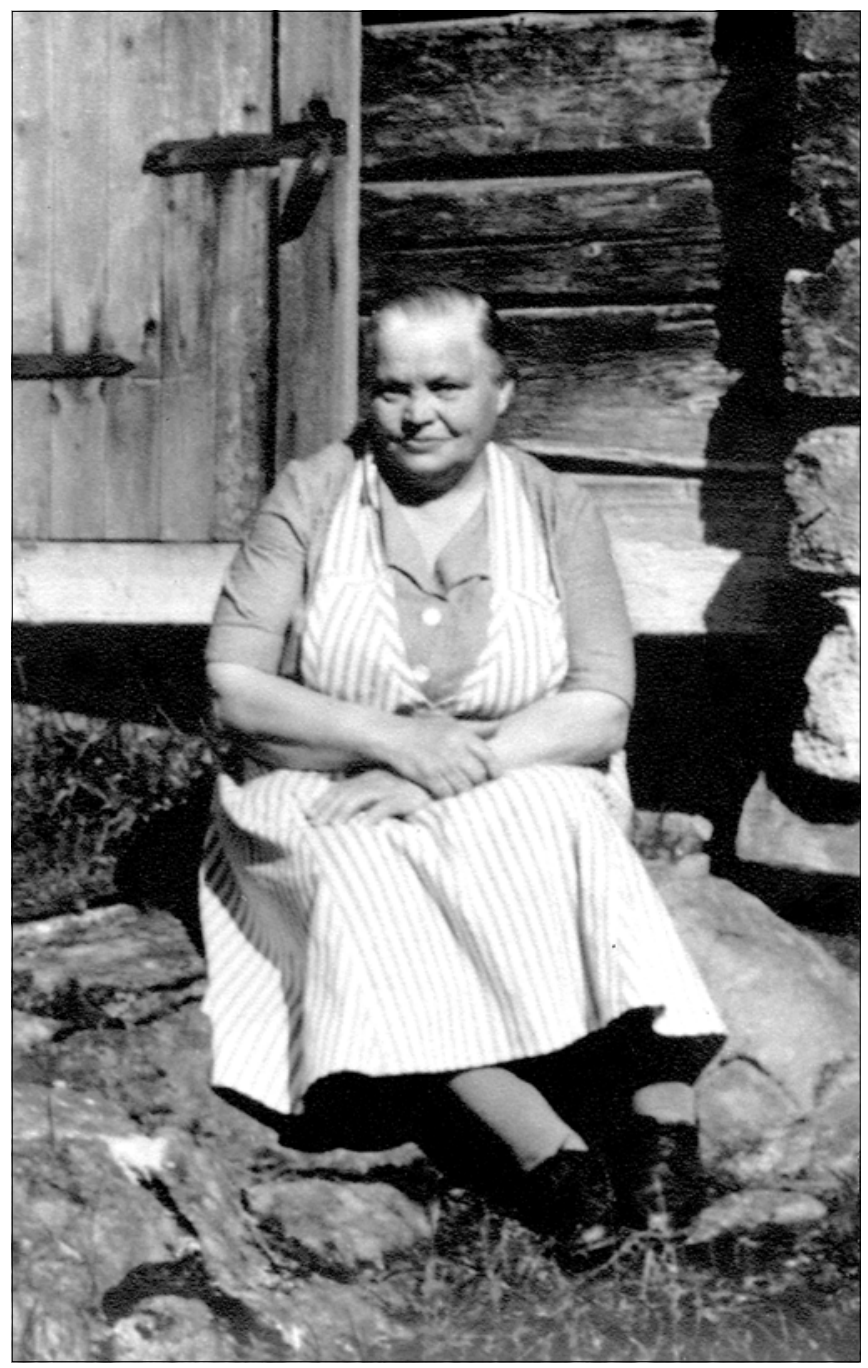

Figure 3. Olga Nord, the main informant of folklore collector Ida Lusenius, in front of her cottage in the 1960s. Source: private collection of Reino Luoto.

Ida Lusenius (née Knuth, 1894-1970) was born in the neighbouring parish of Karkkila as an illegitimate daughter of a peasant woman who worked as a maid, a masseuse and a traditional healer. Ida Lusenius herself became a trained dairymaid, but had to quit her job in the 1920s because of lung disease. Her illness was cured and she married the gatekeeper of the Högfors ironworks. ${ }^{8}$ She sent some collections to the archives in 1965, including a copy of her manuscript songbook from the 1920s. Her main informant was her neighbour Olga Nord (1899-1970), the daughter of a working class family who had written to The Enlightener in her youth. Many of the songs in the collection are adaptations of broadsheets published in the 1920s. The first decades of the 20th century were the last heyday or, 
as some might say, a period of deterioration for the broadsheets (Asplund 1994: 36; Saunio \& Tuovinen 1978: 16-23). The songs published in these last broadsheets were comic or romantic in tone.

The collections of Kustaa Raunio and Ida Lusenius depict the discussions of love in separate groups of young men and women. The gender system in the community of Högfors was rigid, and based on hierarchical patriarchy. The ironworks employed most of the male members of the community, while most of the women were housewives and economically dependent on their husbands. A substantial amount of the women's time was devoted to carrying and heating water for their husbands, sons and lodgers so that they could wash up after the working day. The workers were ruled by the patrons and foremen, but they in turn had control over younger workers (often their own sons), wives and children (Rentola 1992: 729; Salmi-Niklander 1999; 2004: 364-365).

The labour movement introduced new ideas of masculinity and femininity into the industrial community of Högfors. The Social Democratic Youth Club served as a common conversational community for young unmarried men and women. The young men worked in the ironworks, while the young women served as maids or worked on the farm owned by the ironworks. The Enlightener was read aloud at the weekly "meetings with a program". Most of the articles were written under pseudonyms, which could be feminine (Repekka, Vagrant girl), masculine (Justus, Vagabond boy) or gender-neutral (Comrade, Observer, Worker, Thinker, Pen). The names of the editors of each issue were published, so that in most cases readers or listeners could probably guess who the writer of each text was. Some topics had to be avoided in this conversational community of young men and women, but it did provide an audience for presenting new themes and interpretations.

\section{SEDUCED AND FALLEN WOMEN}

I have observed the changes in the love stories appearing in The Enlightener. Some of them were copied or adopted from printed publications, but nevertheless they commented on the events and tensions in the local community. A typical ending of a love story in the 1910s was the death of the heroine, and sometimes also of the hero; she dies in childbirth or commits suicide. There was a change at the end of the 1910s, and open endings were typical of the stories published in The Enlightener in the 1920s. The problems between men and women were solved or remained unsolved, but nobody had to die (Salmi-Niklander 1996; 2004: 393419).

The changes in love stories and the tension between fictionalisation and localisation come out in two love stories written by two young working-class men with literary talent, brothers Lennart (1896-1929) and Martti Berghäll (b. 1897) in 1914 and 1917, respectively. The themes of love and sexuality were introduced in The Enlightener by Lennart Berghäll, in his short story entitled The Ordinary Story which he read out aloud at the meeting on December 25th (sic!), 1914, and signed with his initials. The subtitle of the story is According to real events, but these events are fictionalized. An omniscient narrator tells the story of a 16-year- 
old girl, Fanny Helenius, who is "as ignorant of sex as many of her agemates" and is therefore an easy victim for a log driver, Kalle Kangas, who seduces her in the forest under the August moonlight after they met at a farmhouse dance:

The night passed into the morning, and only the moon knows what happened in the forest. A light breeze swayed the tops of the trees, the first rays of the sun were reflected on the earth. Fanny did not really understand what had happened and Kalle could not judge the extent of his crime. Nine months had passed. Fanny was lying in childbed. A week earlier she had been to the priest with Kalle to get married, and now she had given birth to their son. Fanny was still ill, she had a fever which was getting worse. Her father was poor and could not afford a doctor, and Kalle had no money either. She died deep in the heart of the forest while the spring was at its height. [Underlined lines are identical with the original.]

The Ordinary Story relates to the tradition of realistic and working class literature of the late 19th and the early 20th century, in which the theme of "a fallen woman" was common. ${ }^{9}$ Many realistic writers (e.g., Juhani Aho) described love and sexuality from the woman's point of view, but presenting a story like this to a small group of young people in a small community like Högfors was both a delicate and a revolutionary event. The story is a kind of a triangle drama between Fanny, Kalle and the omniscient narrator. Lennart Berghäll takes distance from the moral values of the young men in the community, but he also describes Fanny as a totally helpless victim.

The greatest culprit for Fanny's tragedy is the society, which does not provide her sex education or medical care.

Lennart Berghäll's younger brother Martti "inherited" the editorship of The Enlightener after Lennart moved to Helsinki in $1915 .^{10}$ Martti's short story Hilma was published in The Enlightener in November 1917 under the masculine pseudonym "Esa". It is also a fictionalised story, set in an anonymous industrial community in Southern Finland. Apparently, Hilma reflects the events in Karkkila during the First World War, when Russian troops were quartered in the town (Rentola 1992: 613-615). The heroine, a young working-class girl Hilma is happily courting a working man Toivo, but she becomes attracted by the uniforms and manners of the Russian soldiers and follows them to the barracks one time after another:

About 1 o'clock at night Hilma returned home, shivering with cold and bothered by her conscience. She told her parents she had been at a meeting of the Salvation Army and left there with Toivo, but since it was a beautiful spring evening they had walked up and down the road for a while. Her parents believed her, since she had often been out with Toivo in the evenings.

[---] Two months later and it's Midsummer. Hilma has spent many nights with the soldiers during this time, always regretting it during the day, but in the evening she was always ready to go to the barracks. Her parents had 
found out about this and had given her many warnings, Toivo had also gotten to know about her new boyfriend, so he thought himself free from his relationship with her.

Toivo still forgives Hilma after receiving her letter of repentance. However, they finally separate and leave their home town: Hilma ends up as a prostitute and a single mother in Helsinki, and Toivo as a vagrant worker. The story is open-ended, and both Hilma and Toivo stay alive. Unlike Fanny Helenius, Hilma is not depicted as a helpless victim, but as a weak character that lapses into vice time after time in spite of her repentance and the patience of her fiancé (SalmiNiklander 2004: 403-405).

The narratives of love in The Enlightener, which I have called "non-gendered love stories", represent localisation of printed texts (Salmi-Niklander 2004: 406-409). The first example I found was published in the first issue of The Enlightener in 1915. Untitled, it was signed "Repekka", a feminine pseudonym:

I walked one summer night by your window. There behind the white curtains white and red roses bloomed. You, my friend, sat in the middle of the flowers, they were the flowers of your heart. The white flowers were the flowers of pain and the red ones were the flowers of joy and happiness. From each of your tears burst a new white flower. From each of your smiles a new red one. And your cheeks paled and glowed in turn. I stopped under your window and I saw now the white, now the red. When I stepped forward you placed flowers in my hands. I took them with me, held them to my breast and watered them with my tears. And the roses grew and burst into full bloom. Take your roses back, do take them for they are the flowers of your heart.

Reading this story for the first time I took it for granted that the actors were a man under the window and a woman at the window, and that the story described their romantic love. After several readings I realized that love was not once mentioned in the story, nor was the gender of the actors revealed. The person at the window is quite obviously a woman, but the behaviour of the narrating I is not masculine, at least by the average standards of the Högfors community.

The story gives a completely different picture of love and affection than The Ordinary Story or Hilma: there is no sexuality, no biology, no society, not even men and women as clearly defined characters. The love described in the story is rather the symbolic meeting of androgynous soulmates in a totally fictional world. Flower symbolism, carrying both ideological and emotional meanings is a typical feature of "non-gendered love stories", which reflect the neo-platonic nature of the discussions of love among the working-class youth but were re-interpreted in local communities (Salmi-Niklander 2002; 2004: 406-409). 


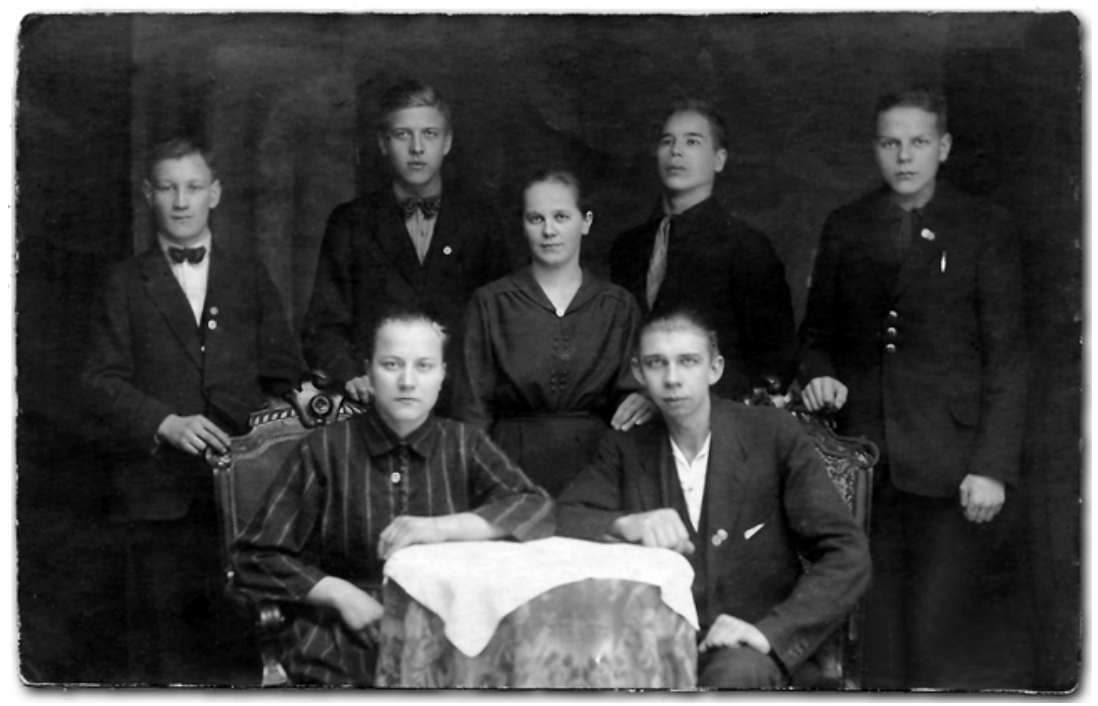

Figure 4. Some members of the Högfors social democratic youth club in a group photograph at the beginning of the 1920s. Source: Karkkila Workers' Museum.

\section{GOOD GIRLS, BAD GIRLS}

At first sight, it seems that there is little to compare between the prose narratives in The Enlightener and the songs in the collections of Kustaa Raunio and Ida Lusenius. However, even though love stories and popular songs belong to different narrative contexts, their comparison here reveals common underlying social and emotional dynamics. Even though most songs are not narrative in content, some of them include a frame story, which gives them new meanings.

Anneli Asplund (1972) has discussed the changing ideas of love in Finnish folk songs. She observed two apparently contradictory tendences in the love songs of the late 19th and early 20th century: on the one hand, faithful, all-conquering love is praised in many of them, but on the other hand many songs describe the love adventures of light-minded young men and women. This contradiction comes out in the boys' and the girls' songs in the folklore collections of Kustaa Raunio and Ida Lusenius.

Many of the girls' songs in the collection of Ida Lusenius have plots parallel with love stories published in The Enlightener before the Civil War. The heroine is warned by her mother never to fall in love. However, the girl does not obey her mother, and is deceived. The solutions are tragic, even in the last broadsheets published in the 1920s, as the heroine commits suicide or ends up in prison, probably after committing infanticide. ${ }^{11}$ Parallel motifs are evident even in the oldest folk song in the collections of Ida Lusenius, a song which Olga Nord had learned from her mother Elina Nord. The song itself seems quite innocent, but the frame story explains the gloomy context: by repeating her short and simple song over 
and over again, the female shepherd reveals a child-murder she had committed while she was out in the woods with the cattle: ${ }^{12}$

Kutitin kutitin kumppanin Kutitin kutitin kuoliaaks. Kätkin suohon sammalistoon ison ladon eteen.
I tickled, I tickled my friend, I tickled, I tickled [him/her] to death.

I hid [him/her] in the swamp, in the moss, In front of the big barn.

(SKS. Ida Lusenius. Karkkila. KT 355: 812-813).

Regardless of their traditional solutions, the love songs in the broadsheets of the 1920s have some modern overtones. The mother is not advising her daughter to marry a rich man, she is telling her never to fall in love at all. This advice indicates that a woman can manage in life on her own. It also supports the observation made by many historians and ethnologists: the modernisation project of Finnish women was based on chastity and self-control (Pohjola-Vilkuna 1995: 114137; Vehkalahti 2000: 143-144). A common metaphor in these songs is the "boat of life", which the girl should be steering herself.

A song from the manuscript songbook of Ida Lusenius, titled The Waltz, expresses how young women dreamed of young men singing to them. It is an adaptation of a popular romantic song published in several broadsheets in the 1910s entitled either To My Girl or Autumn Emotions. ${ }^{13}$ The variant in Ida Lusenius's collection is quite different from the printed broadsheets' version:
Laulu (valssi)
Song (a waltz)

Lausu sä mulle mun impeni vieno

Oh tell me, my gentle maiden mikä on surusi suurin syy.

The greatest reason for your grief

Ja kerro sä mulle mun tyttöni armas And tell me, my darling girl, miksi on miälesi murheinen (suruinen). Why is your mind so sorrowful.

Jos voisin pyyhkiä otsaltasi

surun tummat pilvet pois, ja raastavan tuskan rinnastasi, et sielusi levossa (rauhassa) ois.

Ettei sun silmäsi siniset ja suuret kyynel' helmistä kostuisi, eikä sun äänesi heleän kirkas surun sävelistä sortuisi.

Mies voipi lempiä yhtä ja toista kuulua hetken kenelle vaan. Naiselle tok' lempi on suurenmoista, hän lempivi lempivi kerran vaan.
If only I could wipe from your forehead

The dark clouds of sorrow, And the racking pain out of your heart, So that your mind would be in peace.

So that your big blue eyes, Would not be filled with teardrops, And your clear and melodious voice, Would not break with tones of sorrow.

A man can love one or another, Belong for a moment to anyone. For a woman the love is splendid, As she loves only once. 
The song is comparable to the "non-gendered love stories". It leaves quite a frustrating role for the I narrator, a young man who is patiently waiting for a young woman to wipe her tears and stop mourning, probably after another man. ${ }^{14}$ The real men's songs in the oral tradition of Karkkila were quite different: most of those in Kustaa Raunio's collection express straightforward sexual desire, often with misogynous overtones.

Most interesting, from my perspective, are some of the narrative men's songs in which the actors are real characters, not merely sexual organs. One of these is $A$ Song from Forssa. ${ }^{15}$ Kustaa Raunio describes the historical context of this song carefully: it was performed to him by a man who had moved to Karkkila from the industrial town Forssa (about 45 kilometres north-west of Karkkila). The heroine is a dairy maid, Manta Salin, who had been living in the countryside, in the parish of Jokioinen, close to Forssa. According to the frame story, she took the boys who had made up this song to court for slander. The boys sang and danced this song in court, and were not fined because the song had the melody of a polka. This historical background is quite dubious, since all the variants of the song about Manta Salin at the Folklore Archives of Finnish Literature Society were collected in the region of Karkkila. The song has many verses and motifs that are similar to those in other songs dedicated to loose-living women in other parts of Finland.$^{16}$ The song describes in great detail Manta Salin's vanity, her fancy dressing and sexual affairs with various men. One verse mentions ancient motifs referring to female sexual organs, as Manta is said to have had inch-long teeth in her vagina (Apo 1995: 13-17).

Olga Nord performed the girls' variant of the same song to Ida Lusenius, although she omitted two verses, probably because of their obscenity. ${ }^{17}$ The girls' song is distanced from the historical background: in the end, the loose-living Manta is dead, as all the bad girls have to die, but she gets a marble stone on her grave. This draws a parallel with the folk songs about the famous knife fighters of western Finland.

A comparison of these songs shows the misogynous features of the boys' songs in a different light: the song slanders Manta, but she stays alive, has children and apparently enjoys her life to the full extent. Parallel solutions are typical of narrative boys' songs, in which most immoral people commit the worst crimes, but nevertheless they stay alive and even procreate.

\section{REWRITING AND RE-INTERPRETATION}

Outlining the communication circuit of the working-class youth provides tools for the interpretation of parallels and contradictions, continuities and discontinuities in heterogenous materials. It also leads to a re-evaluation of the question of originality. The manuscript culture provided a medium for creative interplay between the oral and the written. Many songs and stories adopted from printed sources went through creative processes of rewriting in manuscript songbooks and hand- 
written newspapers and were given still new meanings in oral performances. Even the texts that were copied word for word from a printed source, a journal of the labour movement or a broadsheet, gained new individual and social meanings when they were performed and re-interpreted in the local community.

Robert Darnton (2000: 30) questioned the categories of élite and popular culture, as well as of orality and literacy, in his research on communication networks in 18th-century Paris. In my research on the culture of working-class youth in early 20th-century Finland I found the categories of the oral and the written, the local and the national also to be intertwined in a confusing manner. A good example of this is the song about Manta Salin. The historical frame story of the song is questionable, and motifs and whole verses are adopted from various similar songs from other parts of Finland. In spite of the geographical distance, this song probably referes to people, events and moral values in the local community of Högfors. The love stories in The Enlightener had quite different functions from those of popular songs, and utilised different stylistic devices, but they also made it possible to create a narrative distance from personal experiences and local events.

\section{Comments}

1 The name Karkkila came in use at the end of the $1920 \mathrm{~s}$, when the industrial community of Högfors was separated from the surrounding parish of Pyhäjärvi and became an independent township. When referring to events of the 19 th and the early 20 th century, I have used the names Högfors and Pyhäjärvi.

2 The Enlightener is preserved in the Workers' Archives in Helsinki.

${ }^{3}$ Among recent studies on the manuscript medium are Scribal Publication in 17th Century England by Harold Love (1993) and Writing Women's Literary History by Margaret Ezell (1993).

${ }^{4}$ Hand-written newspapers produced by university students are discussed by Matti Klinge (1967: 135-137), family and school papers by Ritva Haavikko (1998), papers of the workers' movement by Jari Ehrnrooth (1992), and papers of the agrarian youth movement by Jaakko Numminen (1961: 459-471).

${ }^{5}$ Lauri Honko (1981: 19-22) discusses two forms of the milieu-morphological adaptation of oral tradition: familiarisation means the adaptation of oral narratives to familiar natural settings. Localisation means "linking a certain tradition to a spot or place in the experience of experienced physical milieu". The theoretical framework for these terms is the ecology of tradition.

6 The copying and rewriting of texts in the early modern manuscript culture is also discussed by Margaret Ezell (1993: 33-37) and Harold Love (1993: 13-22).

${ }^{7}$ Salmi-Niklander 2004: 78-79; interviews with Kustaa Raunio's son Niilo Raunio (SKSÄ 111.1996) and daughter Anna-Liisa Lindstedt (2001). 
${ }^{8}$ Salmi-Niklander 2004: 77. Information on the life of Ida Lusenius was given by her son Aki Lusenius (2003).

${ }^{9}$ The theme of "a fallen woman" in working-class literature is discussed by Raoul Palmgren (1966: 387-390, 426-432).

${ }^{10}$ Lennart Berghäll never returned to his home town. He fled to Canada in 1925 after having been sentenced to prison for spreading communist leaflets in Helsinki. He died in Canada in 1929 (Salmi-Niklander 2005).

${ }^{11}$ For example, in the song Pohjolan tyttö (Maid of the North), published in several broadsheets in the 1920s, the heroine falls in love with a young Italian in spite of her mother's warnings. She is deceived and plans to end her life with a dagger stab. This song is also included in the manuscript songbook of Ida Lusenius as a variant of the one that appeared in the printed broadsheets (SKS. Ida Lusenius. KT 355:774).

12 Several variants of this song are included in the collections from southern Karelia in Suomen Kansan Vanhat Runot (SKVR), the printed anthology of Finnish folk poetry. In most variants, the singer refers to a "fellow shepherd" whom s/he has tickled to death (SKVR XIII/1: 544-546; XIII/4: 10395-10396). One variant includes a frame story, referring to an occasion on which shepherd boys tickled to death (= raped and murdered?) a shepherd girl (SKVR XIII/1: 545). The informants of all the variants of this song were women.

${ }^{13}$ See the catalogue of broadsheets in the collections of Helsinki University Library (Hultin 1931). The song is also included in the latest, partly revised and improved version of Johan Lindstedt's popular songbook Laululipas (1931: 611).

${ }^{14}$ This aspect comes out more clearly in the printed broadsheets, in which the narrative I changes in the middle of the song: in the last verses a young girl is lamenting her unhappy love to a debauched young man.

${ }^{15}$ SKS. Ul. Pyhäjärvi. Kustaa Raunio. KRK 54:252.1935.

${ }^{16}$ For example, a song about Särpin Maiju in Längelmäki has many similar verses (SKS. Nakkila. Vihtori Grönroos. KRK 14-16: 207. 1935).

${ }^{17}$ SKS. Karkkila. Ida Lusenius. KT 355:815. 1965.

\section{References}

Apo, Satu 1995. Naisen väki. Tutkimuksia suomalaisten kansanomaisesta kulttuurista ja ajattelusta [Women's Power. Studies on Finnish Popular Culture and Thought]. Helsinki: Hanki ja Jää.

Asplund, Anneli 1972. Kansanlaulustomme eroottisten asenteiden muutoksista [On the Changes of Erotic Ideas in Our Folk songs]. Kotiseutu, 1, pp. 32-39.

Asplund, Anneli 1994. Balladeja ja arkkiveisuja. Suomalaisia kertomalauluja [Ballads and Broadsheets. Finnish Narrative Songs]. Helsinki: Suomalaisen Kirjallisuuden Seura.

Bristol, Michael \& Marotti, Arthur 2000. Introduction. Marotti, A. \& Bristol, M. (eds.): Print, Manuscript \& Performance. The Changing Relations of the Media in Early Modern England. Columbus: Ohio State University Press. 
Darnton, Robert 1996. The Forbidden Best-Sellers of Pre-Revolutionary France. New York \& London: W.W. Norton \& Company.

Darnton, Robert 2000. An Early Information Society: News and the Media in Eighteenth-Century Paris. American Historical Review, 1 (105), pp. 1-35. http:// www.indiana.edu/ ahr/darnton/

Ehrnrooth, Jari 1992. Sanan vallassa, vihan voimalla. Sosialistiset vallankumousopit ja niiden vaikutus Suomen työväenliikkeessä 1905-1914 [English abstract: "Power of the Word, Force of Hatred. Socialist Revolutionary Doctrines and their Effects in the Finnish Workers' Movement 1905-1914"]. Helsinki: Suomen Historiallinen Seura.

Ezell, Margaret 1993. Writing Women's Literary History. Baltimore \& London: John Hopkins University Press.

Haavikko, Ritva 1998. Kirjoittavat lapset. Huomioita kirjailijaksi kasvamisen psykologisista ja sosiaalisista edellytyksistä [Writing Children. Observations on the Psychological and Sociological Background of Becoming a Writer]. Ilomäki, Henni et al. (eds.). Salaamatta. Helsinki: Suomalaisen Kirjallisuuden Seura.

Honko, Lauri 1981. Four Forms of Adaptation of Tradition. Honko, Lauri \& Voigt, Vilmos (eds.). Adaptation, Change and Decline in Oral Literature. Studia Fennica, 26. Helsinki: Suomalaisen Kirjallisuuden Seura.

Hultin, Arvid 1931. Luettelo Helsingin yliopiston kirjaston arkkikirjallisuudesta II. Maalliset arkkiveisut [A Catalogue on Broadsheet Literature at Helsinki University Library]. Helsinki: Helsingin yliopiston kirjasto.

Klinge, Matti 1967. Ylioppilaskunnan historia. Toinen osa 1853-1871 [The History of the Student Union in the University of Helsinki. Part two, 1835-1871]. Porvoo: WSOY.

Love, Harold 1993. Scribal Publication in Seventeenth-Century England. Oxford: Clarendon Press.

Mäkinen, Ilkka 1997. Nödvändighet af Laina Kirjasto. Modernin lukuhalun synty ja lukemisen instituutiot [The Necessity for the Lending Library: The Introduction of Modern 'Desire to Read' in Finland and the Institutions of Reading]. Helsinki: Suomalaisen Kirjallisuuden Seura.

Numminen, Jaakko 1961. Suomen nuorisoseuraliikkeen historia I. Vuodet 1881-1905 [The History of the Finnish Agrarian Youth Movement, 1. The Years 1881-1905]. Keuruu: Otava.

Palmgren, Raoul 1966. Joukkosydän II. Vanhan työväenliikkeemme kaunokirjallisuus [The Collective Heart, 2. The Literature of Our Old Workers' Movement]. Porvoo \& Helsinki: WSOY.

Pohjola-Vilkuna, Kirsi 1995. Eros kylässä. Maaseudun luvaton seksuaalisuus vuosisadan vaihteessa [The Eros in the Village. Illegal Sexuality in the Countryside at the Turn of the 20th Century]. Helsinki: Suomalaisen kirjallisuuden seura.

Rentola, Kimmo 1992. Karkkilan historia. Toinen osa [The History of Karkkila, 2]. Aalto, Seppo \& Rentola, Kimmo (eds.). Karkkilan historia. Karkkila: Karkkilan kaupunki.

Salmi-Niklander, Kirsti 1996. Lennart ja Fanny Lemmenlaaksossa [Lennart and Fanny in the Valley of Love]. Rahikainen, Marjatta (ed.). Matkoja moderniin. Helsinki: Suomen Historiallinen Seura.

Salmi-Niklander, Kirsti 1999. Soot and Sweat. The Factory in the Local Tradition of Karkkila. Hänninen, Sakari et al. (eds.). Meeting Local Challenges - Mapping Industrial Identities. Helsinki: Finnish Society for Labour History.

Salmi-Niklander, Kirsti 2002. Pahan tytön viimeiset sanat. 1900-luvun alun työläisnuorisoliikkeen sukupuolikeskustelua 1900-luvun alkupuolella [The Bad Girl's Last Words. Discussion on Gender among the Working-Class Youth at the Beginning of the 20th Century]. Aaltonen, Sanna \& Honkatukia, Päivi (eds.). Tulkintoja tytöistä. Helsinki: Suomalaisen Kirjallisuuden Seura. 
Salmi-Niklander, Kirsti 2004. Itsekasvatusta ja kapinaa. Tutkimus Karkkilan työläisnuorten kirjoittavasta keskusteluyhteisöstä 1910- ja 1920-luvuilla [Self-Education and Rebellion. A Conversational Community of Working-Class Youth in Karkkila During the 1910s and the 1920s]. Helsinki: Suomalaisen Kirjallisuuden Seura.

Salmi-Niklander, Kirsti 2005. "Villien voimain kaihoisa mieli". Lennart Berghällin lyhyt ja pitkä elämä [The Short and Long Life of Lennart Berghäll]. Jalkanen, Marita (ed.). Elämää arkistossa. Kansan Arkisto 60 vuotta. Helsinki: Yhteiskunnallinen arkistosäätiö.

Stahl, Sandra Dolby 1989. Literary Folkloristics and the Personal Narrative. Bloomington \& Indianapolis: Indiana University Press.

Saunio, Ilpo \& Tuovinen, Timo 1978. Edestä aattehen. Suomalaisia työväenlauluja 1890-1938 [Finnish Working-Class Songs 1890-1938]. Helsinki: Tammi.

Valpola, Tiina 1999. A Town with a Heart of Iron. Traces of Casting in the Karkkila Townscape. Hänninen, Sakari et al. (eds.). Meeting local challenges - Mapping Industrial Identities. Helsinki: Finnish Society for Labour History.

Vehkalahti, Kaisa 2000. Jazz-tyttö ja naistenlehtien siveä katse [The Jazz-Girl and the Virtuous Look in the Women's Magazines]. Immonen, Kari et al. (eds.). Modernin lumo ja pelko. Kymmenen kirjoitusta 1800-1900-lukujen vaihteen sukupuolisuudesta. Helsinki: Suomalaisen Kirjallisuuden Seura.

\section{Printed sources}

Broadsheet collections in Helsinki University Library:

1. Seitsemän kaunista Lempi-laulua. Pori 1912.

2. Wäyrynen, Paawo: Syys-tunnelma. Lahti 1914.

3. [Syystunnelma]. Vaasa 1915.

4. Kolme surullista sekä kaksi Kupletti-laulua. Pori 1916.

5. Syysyön unelma. [1916-1917]

6. Kahdeksan kaunista Lempi-laulua nuorison huviksi. Pori 1921.

Lindstedt, Johan 1931. Laululipas. Jälkimmäinen osa [Songs. Another Set]. Helsinki: Kirja.

SKVR XIII:1 = Suomen Kansan Vanhat Runot.XIII: Etelä-Karjalan runot 1 [Old Finnish

Folk Songs. XIII: South-West Finnish Folk Songs 1]. 1936. Helsinki: Suomalaisen Kirjallisuuden Seura.

SKVR XIII:4 = Suomen Kansan Vanhat Runot. XIII: Etelä-Karjalan runot 4 [Old Finnish Folk Songs. XIII: South-West Finnish Folk Songs 4]. 1945. Helsinki: Suomalaisen Kirjallisuuden Seura.

\section{Manuscript collections}

Finnish Literature Society, Folklore archives:

- collections of Kustaa Raunio: Ul. Pyhäjärvi. Kustaa Raunio. KRK 54. 1935.

- collections of Ida Lusenius: Karkkila. Ida Lusenius. KT 355. 1965.

- interview with Niilo Raunio (Kirsti Salmi-Niklander, December 1995): SKSÄ 111.1996

Workers' Archives:

- archives of the Högfors Social Democratic Youth club:

The Enlightener, hand-written newspaper 1914-1925.1 
Kirsti Salmi-Niklander

\section{Private accounts}

- interviews with Anna-Liisa Lindstedt (2001) and Aki Lusenius (2003), transcripts in the possession of the author. 